УДК 339.172(100):004.738.5

\author{
Andriy Syshchuk, \\ PhD in Economic Science, Associate Professor \\ Lesia Ukrainka Eastern Europen National University, \\ Department of International Economic Relations and Project Management \\ Lutsk, ORCID ID 0000-0003-2973-203X \\ e-mail: asyshchuk@gmail.com \\ Viktoria Khirova, \\ first-year student of Master specialty \\ «International Economic Relations» of \\ Lesia Ukrainka Eastern Europen National University, \\ Department of International Economic Relations and Project Management \\ Lutsk, ORCID ID 0000-0002-7379-8063 \\ e-mail: vika.khirova98@gmail.com
}

\author{
https://doi.org/10.29038/2411-4014-2019-04-15-24
}

\title{
INTERNATIONAL ELECTRONIC STOCK TRADING: MECHANISM OF FUNCTIONING AND CURRENT TRENDS
}

\begin{abstract}
Modern international electronic stock trading is becoming increasingly important in the organization of the system of international trade relations. Several studies of the domestic and foreign scientists have highlighted various aspects of the place and role of electronic exchanges in trade relations between countries. At the same time, the peculiarities of the mechanism of functioning of the international e-commerce, which is constantly evolving and improving, need to be studied both from the point of view of theory and practice.

Electronic exchanges have created and implemented their own mechanism of functioning, which turns them into the most organized form of international trade. It is substantiated that trends and key features of the development of electronic exchanges can be tracked and forecasted with the help of relevant stock indices. The main features and the most important aspects of the development of electronic exchanges are determined, based on the analysis of stock indices of the two largest electronic exchanges in the world, the geographical structure of electronic stock exchanges and the dynamics of the use of artificial intelligence in the exchange trading process. Here also highlighted the negative and positive interdependencies regarding the future development of international e-commerce.

Keywords: electronic exchanges, stock exchange trade, stock indices, mechanism of functioning of international electronic exchange trading, trends of international electronic exchange trade.
\end{abstract}

Сищук Андрей, кандидат экономических наук, доцент, Восточноевропейский национальный университет имени Леси Украинки, кафедра международных экономических отношений и управления проектами, г. Луцк

Хирова Виктория студентка первого курса магистратуры по специальности «Международные экономические отношения»,

Восточноевропейский национальный университет имени Леси Украинки, кафедра международных экономических отношений и управления проектами, г. Луцк

\section{МЕЖДУНАРОДНАЯ ЭЛЕКТРОННАЯ БИРЖЕВАЯ ТОРГОВЛЯ: МЕХАНИЗМ ФУНКЦИОНИРОВАНИЯ И СОВРЕМЕННЫЕ ТЕНДЕНЦИИ РАЗВИТИЯ}

Аннотация. Современная международная электронная биржевая торговля приобретает все большее значение в организации системы международных торговых отношений. Появилось ряд иследований отечественных и зарубежных ученых, посвященных различным аспектам места и роли электронных бирж в торговых отношениях между странами. Вместе с тем, особенности механизма функционирования 
международной электронной биржевой торговли постоянно эволюционируют и совершенствуьтся, требуют дальнейшего изучения как с точки зрения теории, так и практики.

В процессе своей деятельности электронные биржи создали и реализуют собственный механизм функционирования, превращает их в наиболее организованную форму международной торговли. Обосновано, что тренды и основные особенности развития электронных бирж можно отслеживать и прогнозировать с помощью соответствующих фондовых индексов. Определены основные особенности и наиболее важные аспекты развития электронных бирж на основе анализа фондовых индексов двух крупнейших электронных бирж мира, географического распределения объемов электронных биржевых торгов и динамики использования искусственного интеллекта в процессе биржевой торговли. Освещены негативные и позитивные взаимозависимости развития международной электронной биржевой торговли в будущем.

Ключевые слова: электронные биржи, биржевые торги, биржевые индексы, механизм функционирования международной электронной биржевой торговли, тренды международной электронной биржевой торговли.

Сищук Андрій, кандидат економічних наук, доцент, Східносвропейський національний університет імені Лесі Украӥнки кафедра міжнародних економічних відносин та управління проектами, м. Луцьк Хірова Вікторія,
студентка першого курсу магістратури зі спеціальності,
«Міжнародні економічні відносини»,
Східноєвропейський національний університет імені Лесі Українки,
кафедра міжнародних економічних відносин та управління проектами,
м. Луцьк МІЖНАРОДНА ЕЛЕКТРОННА БІРЖОВА ТОРГІВЛЯ: МЕХАНІЗМ
ФУНКЦІОНУВАННЯ ТА СУЧАСІ ТЕНДЕНЦІЇ РОЗВИТКУ

Анотація. Сучасна міжнародна електронна біржова торгівля набуває дедалі більшого значення в організації системи міжнародних торгівельних відносин. 3'явилося ряд досліжень вітчизняних і зарубіжних вчених, присвячених різним аспектам місця і ролі електронних бірж у торговельних відносинах між країнами. Разом 3 тим, особливості механізму функціонування міжнародної електронної біржової торгівлі, що постійно еволюціонує і удосконалюється, потребують подальшого вивчення як з точки зору теорії, так і практики.

Метою даної наукової роботи є дослідити механізм функціонування сучасної електронної біржової торгівлі, проаналізувати теоретичні основи та практичні аспекти основних тенденцій ії розвитку й виділити взаємозалежності між наявними трендами і власне процесами розвитку.

За результатами досліження, було виявлено, що у процесі своєї діяльності електронні біржі створили та реалізують власний механізм функціонування, що перетворює їх на найбільш організовану форму міжнародної торгівлі.

Як висновок наукової роботи, було обгрунтовано, що тренди й основні особливості розвитку електронних бірж можна відстежувати та прогнозувати за допомогою відповідних фондових індексів. Визначено основні особливості та найбільш важливі аспекти розвитку електронних бірж на основі аналізу фондових індексів двох найбільших електронних бірж світу, географічного розподілу обсягів електронних біржових торгів та динаміки використання штучного інтелекту у процесі біржової торгівлі. Висвітлено негативні та позитивні взаємозалежності стосовно розвитку міжнародної електронної біржової торгівлі у майбутньому.

Ключові слова: електронні біржі, біржові торги, біржові індекси, механізм функціонування міжнародної електронної біржової торгівлі, тренди міжнародної електронної біржової торгівлі.

Formulation of the problem. Today, one of the most important elements of a country's involvement in world economic processes is its participation in the international stock trading. Functioning at the present stage of world market development is impossible without involvement in international stock exchange trading. That is why the relevance of the researches in these spheres is so important because nowadays the international stock trading is a component of market infrastructure, which forms the market environment. 
The analysis of researches and publications. The study of development and formation of electronic stock exchange trading was carried out by such national and foreign researchers as Berysheva E. (the analysis of influence of information technologies on the future of stock markets), Vasylik O. (the study of stock exchanges as a part of the world theory of finance), Akworth W. (research about the state and prospects of the stock market development, the analysis of the stock market of Ukraine, the international currency market Forex and the market of derivative financial instruments), Zhdanova O. (the study of Asian stock exchanges, the analysis of their problems and prospects), Kovalenko M. (research about the functioning of the stock market of Ukraine) and others.

The purpose of the work. At the current stage of global market development, electronic stock exchange trading is actively developing and improving every year, taking different forms and using various new instruments. That is why researches in the sphere of electronic stock exchange is important for its more efficient implementation. The purpose of this article is to analyze the main trends in the development of modern electronic stock trading and to explore the mechanism of its functioning.

Presentation of the main research material. Today, when the mechanism of regulation of global traditional stock trading is quite active, the international electronic stock trading, unfortunately, does not yet have an approved mechanism of regulation. At that moment, the regulation of electronic stock exchanges is based on an endogenous mechanism of regulation, in fact, by their internal regulation - subordination of activity to their own normative documents: the Charter, the rules that determine the activity of the stock exchange as a whole, its divisions and employees [1].

Regarding the exogenous mechanism of regulation of electronic stock trading, it is worth noting that its basis is the subordination of the stock exchange to the normative acts of the state, other organizations, or international agreements. At the state level, external regulation of electronic stock trading is currently the same as the regulation of classical stock trading or absent at all. We believe that neither variants are effective for proper regulation, because electronic stock trading has a few features that are not used in classical stock trading.

Electronic stock trading will not have sense without reaching the international level. One of the main goals of the electronics stock exchange trading process is to integrate all electronic platforms into one global network. Thus, there is a need for global regulation of electronic stock trading. European paper market can be used as an example of international coordination for the electronic stock trading.

Initially, the European paper market was unregulated. The agreements that it entered into were the result of a two-party agreement without establishing arbitration rules and performance standards [2]. However, due to the need to develop general rules, in 1969 the Association of International Securities Market Assosiation (ISMA) and its associated International Primary Market Assosiation (IPMA) was created. ISMA has a dual status, as on the one hand, under UK law, it has the status of a listed exchange, and on the other hand, it is recognized by the Securities and Futures Council (SFA) as an international selfregulatory organization governed by the European securities market. In addition, ISMA is an affiliate member of the International Organization of Securities Commissions (IOSCO) and a member of the International Council of Securities Association [3].

Thus, one way to create the regulatory body for electronic stock trading is to create a specialized international organization or delegate these functions to an existing one. Another way is to create a selfregulatory mechanism by which the participants of the trade themselves will perform the functions of the regulatory body. Blockchain can be used for this.

The key feature of the mechanism of regulation of international electronic stock trading is that the main purpose of electronic stock exchanges is not to make a profit on the stock exchange itself, but to create such trading conditions that will allow large profits to be made to the members of the stock trading, who are mainly members of the exchanges [4]. It is for this purpose the electronic stock exchanges are distinguished as a special form of trading.

The mechanism of electronic exchange activity is not adapted for profit but for creation of convenient market environment for its participants [5]. It has certain specific characteristics:

- remote and permanent format of trade. The organization of electronic stock exchange trading is based on the constant trade that is conducted regularly outside the building of the exchange;

- absence of goods. The product itself is usually absent during the electronic stock exchange. For urgent operations, the product is not even manufactured at the time of the conclusion of the transaction. 
Only when the question is about the immediate delivery, it is required that the goods should be either on the stock exchange or owned by the seller [6];

- certain item of trade. Each electronic stock exchange has a clear list of assets for which it is authorized to trade [7];

- self-organization. Each electronic stock exchange operates in accordance with the rules developed and approved by the stock exchange itself [8].

- open access to market information. The electronic stock exchange system provides open access to all real-time trading information. The form of information is very flexible and can be adjusted by users.

- flexibility of operations. The trader can choose the trading methods independently. In normal mode, trade is carried out continuously when market participants buy and sell assets and the central server selects the appropriate sellers and buyers. However, the features, rules and methods of transactions may change.

- control. A big advantage for a trader is the ability to control all transactions that are transferred to the exchange. In the electronic stock exchange system, you can specify the parameters by which trading will be monitored. The simplest of them is the start and end times of trade [9].

A distinctive feature of modern foreign electronic stock exchanges is the high level of standardization. It provides high efficiency of trade and speed of conclusion of exchange transactions. The objective of an electronic stock exchange is not to supply capital, assets or currency, but to organize, streamline, unify the assets, capital or currency markets [10].

Different mechanisms have been introduced for the effective operation on electronic stock exchanges. Basically, these mechanisms of organization are about ensuring that appropriate computer equipment is available in the form of a central computer connected through the network to other personal computers [8]. However, in more complex cases of organizations the certain elements of exchange electronic systems are distinguished (Fig. 1).

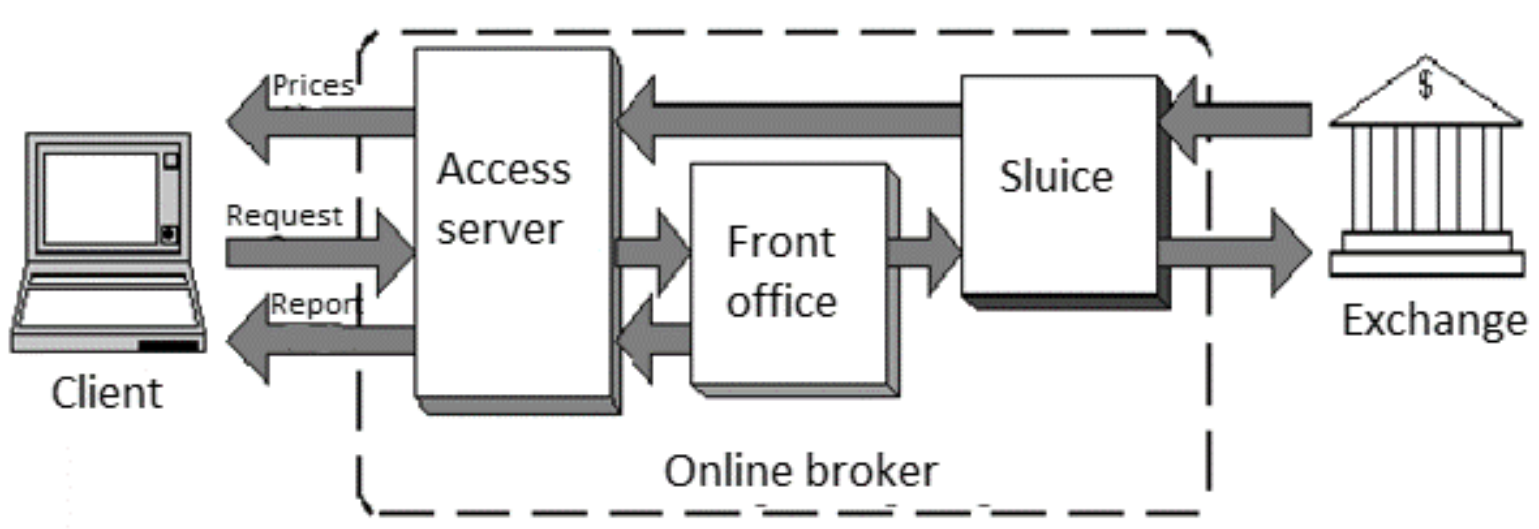

Figure 1. The mechanism of functioning of electronic stock exchanges.

Source: [8].

Among the main elements that are responsible for the functioning of the electronic exchange platforms are:

- Trader Station. With the help of this broker gets access to the transactions on the exchange and to the necessary information for the operations. Also, requests for implementation of certain agreements are provided through the work platform [8];

- front offices - groups of units responsible for direct work with clients and customers. Typical frontoffice functions include communication with clients, receiving and entering for further processing of documents from clients, interaction with other internal units of the electronic exchange platform for providing the client with information, sending information messages to clients, processing incoming calls [8];

- Communications Link - these are special links that provide communication between the central exchange and the broker [8]; 
- central stock exchange system. It is responsible for providing necessary information to exchange participants and fulfilling broker requests. The main requirements for such system are efficiency, reliability, guaranteed access and high speed of information provision [8].

The mechanism of trading on the electronic stock exchange is presented in Figure 2.



Figure. 2. The mechanism of trading on the electronic stock exchange

Source: developed by the authors.

Market research involves analyzing the current situation on the electronic stock exchange. The task of the trader at this stage is to evaluate the prospects and sectors of the stock market. It is also important that the market research is not just an analysis of the sales dynamics, but a comprehensive assessment of the market as a whole. The income from the assets depends on it.

The next stage of trading at the electronic stock exchange is assets selection. The trader approaches this stage in terms of his own needs. Usually, assets with a high degree of trendiness and low volatility are selected for trading.

Risk management involves evaluating the trader's position and assets selected in terms of objectivity. Often, any kind of trade is a very subjective phenomenon that depends on many variables. The task of the trader at this stage is to prevent the wishful thinking.

Quite often, transactions on electronic stock exchanges are not limited with one certain type of assets. Usually, traders continue to "play" on the market, claiming also a share of speculative income. The stage of recruitment and control of positions implies the continuation of the conclusion of the sale and purchase agreements, but on a speculative basis.

Game Changing involves adjusting the strategy chosen by the trader to the current market situation. Electronic stock exchanges are characterized by extremely active dynamics over short periods of time. Thus, the ability of the trader to adapt to the current volatility situation is very important.

The best trends in the development of modern electronic stock exchanges are demonstrated by their dynamics. We can analyze and track the dynamics and features of trading on electronic stock exchanges using stock indexes. It is not uncommon for a particular electronic stock exchange to create its own stock index for calculations and various transactions. Thus, the US electronic stock exchange NASDAQ has its own Nasdaq Composite index, which characterizes the status of all transactions performed on this exchange (Fig. 3). 


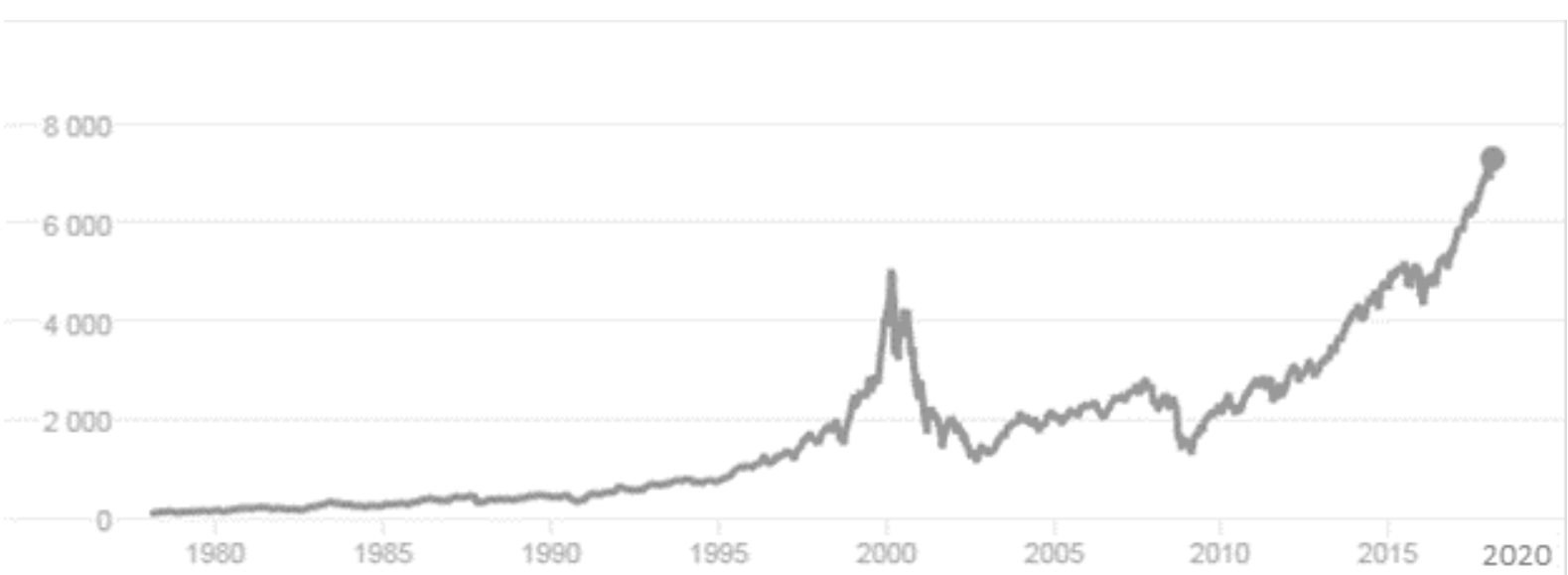

Figure 3. Dynamics of the NASDAQ Composite Index until 2020

Source: [11].

Based on the data on the dynamics of the Nasdaq Composite index submitted on the official resource of the electronic stock exchange NASDAQ, we can conclude its increasing during the period from 1980 to 2020 (Fig. 3).

At first the index was calculated in 1971 with a value of 100 points. In 1974, the index reached its lowest value -54 points, which was due to distrust to the electronic exchange platform. In 1995, the index first rose above 1000 points. Until 2000, the Nasdaq Composite showed an active positive growth trend, which was 5048.62 points. After that, the index began to fall sharply as a result of the crisis caused by the dotcom collapse, which was characterized by the bankruptcy of a large number of companies created by the development of the Silicon Valley economy in the United States. The collapse of the dotcoms caused a massive outflow of financial resources from the Internet economy and a loss of confidence in this type of business, which was also reflected in electronic exchanges in the form of significant volumes of trade decline (Fig. 3).

The negative dynamics of the Nasdaq Composite lasted until 2003, after which the index started to rise during next five years. The creation and successful functioning of a number of established business sites and technologies, which continued to operate effectively despite the overall downturn, as well as the impressive first public offering of Google's private equity, played a significant positive role in this. Electronic stock exchanges have regained the trust of their users, which has resulted in an increase in the volume of trading on them (Fig. 3).

Positive growth of the Nasdaq Composite index and the values of most stock exchange indices continued until 2008. In 2008, there was another significant decline in activity as a result of the global financial crisis. The global financial crisis is marked by the fact that some stock electronic exchanges have ceased to exist.

In the second half of 2009, the global economy stabilized and began to return to its former positions. Trading within the electronic stock exchanges has resumed and started to increase. In 2012, the Nasdaq Composite Index took its pre-crisis position, and in 2016 it set a record at 6,000 points. To date, the dynamics of the index is actively growing and has already exceeded 7000 points.

Particularly noteworthy is also the US stock exchange Euronext NV, which is one of the largest groups formed of two major exchanges - the European (Euronext) and New York (NYSE). At the moment, this stock exchange is one of the largest and most influential in the world. The e-trade system deserves special attention from the NYSE Arca platform, which has been fully automated since 2013.

Analyzing the dynamics of the Euronext NV index during 2014-2019 (Fig. 4), we can also draw some conclusions. 


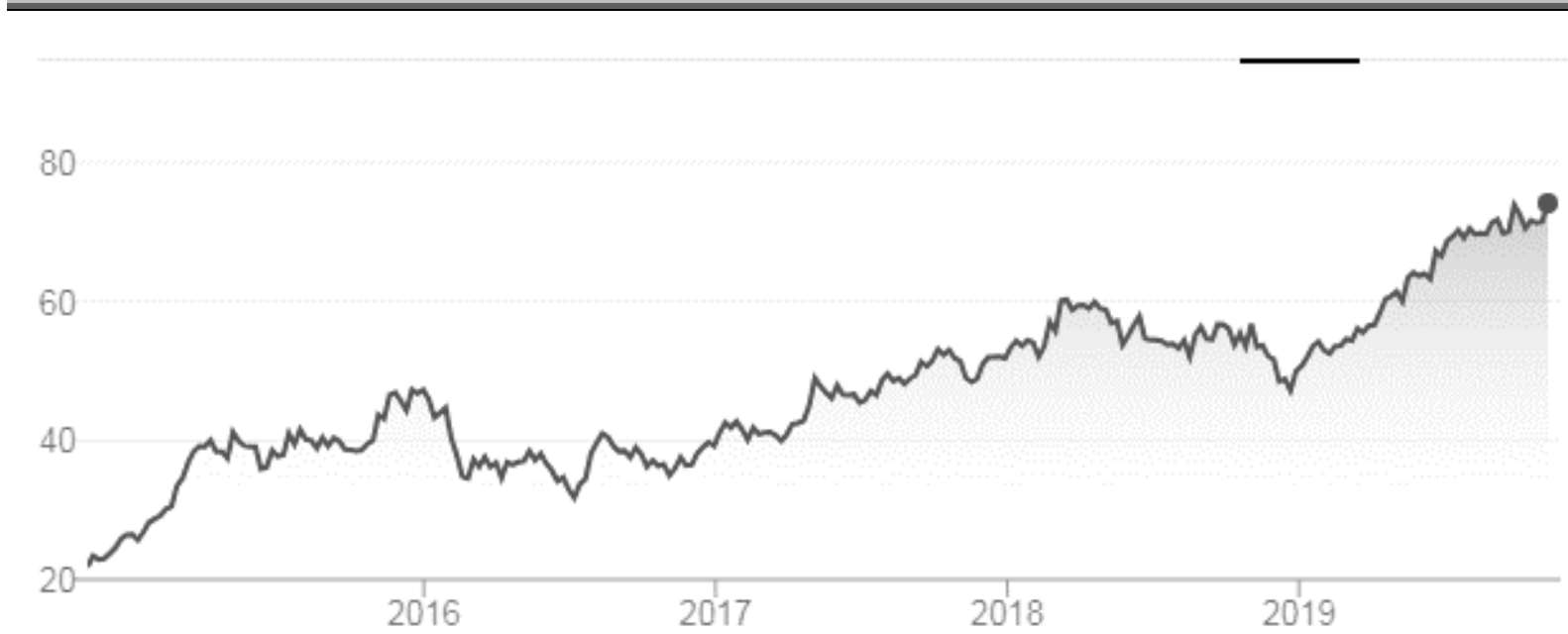

Figure 4. Dynamics of the Euronext NV Index during 2014-2019

Source: [12].

The Euronext NV index calculation system is different from the Nasdaq Composite index and currently does not exceed 60 points. Over the course of its existence, the dynamics of the Euronext NV index have been actively evolving and changing. Thus, in the period from 2013 to 2015, due to the crisis situation of the economies of developing countries and the collapse in their markets, the mentioned index was at the level of 18 points.

The situation has stabilized by 2016. Euronext NV's record high of 48 points was set. However, in July 2016, the situation worsened again. The index collapsed to 31 points. This was attributed to the fall in the stock quotes on the Chinese stock exchanges since July 2015 after a significant "overheating economy" of the country. A large proportion of electronic transactions on the Euronext exchange was conducted with China, so the effects of the negative economic situation in the country also affected the fall of the stock index.

After a sharp collapse in July 2016, there were two more significant falls in the Euronext NV index. However, since then, there has been a dynamic to growth since all the lowest values exceeded the July 2016 figure. Thus, as of November 3, 2019, the Euronext NV index is 74,20 points.

Regarding the dynamics of electronic stock trading by regions, it should be noted that during the period 2008-2018, there were formed their own tendencies of development.

Analyzing the dynamics of world stock trading for 2008-2018 by regions of the world, it can be stated that, as ten years ago, today the active competition of the Asia-Pacific and the North American region in the leader in the volume of electronic stock is observed.

The Asia-Pacific region took the lead in 2010, when the largest electronic stock exchanges in the US and Europe suffered from the effects of the World Financial Crisis, while at the same time the Asia-Pacific region experienced a rise in the stock and bond index. This trend changed in 2012, with Asia-Pacific growth going backwards. North America again took the lead in 2013.

The regional breakdown of e-stock trading activity in 2016 highlighted very significant differences from 2016, when e-stock exchange trading in the Asia-Pacific region was the main engine of growth. In 2017, e-trading activity on the North American stock exchanges increased by $4.8 \%$ and amounted to 8.59 billion contracts, European electronic stock trading activity increased by $8.0 \%$, which amounted to 5.18 billion contracts, and in Latin America an increase of $11.3 \%$ was observed, amounting to 1.62 billion contracts. In 2017, North America and Europe set records in terms of overall e-commerce volume. In contrast, volume in the Asia-Pacific region decreased by 5.3\%, amounting to 9.18 billion contracts. The Asia-Pacific region still accounts for the largest volume of electronic stock trading, but its share in global electronic trading has dropped from $39 \%$ to $36 \%$.

Changes in regional trends have been driven by the fact that the volume of electronic stock trading futures is increasing every year, as opposed to options trading. The decline in electronic stock trading in options trading has been particularly noticeable in the Asia-Pacific region, the electronic stock exchanges of which have mostly relied on trading in this type of contracts. The total number of options contracts traded 
on electronic exchanges in the region decreased by $29.6 \%$, amounting to 2.48 billion contracts in 2017 . This is the lowest level for this region in the last 10 years. The downward trend in the Asia-Pacific region's dynamics in the global electronic stock market continued in 2018.

30000000000

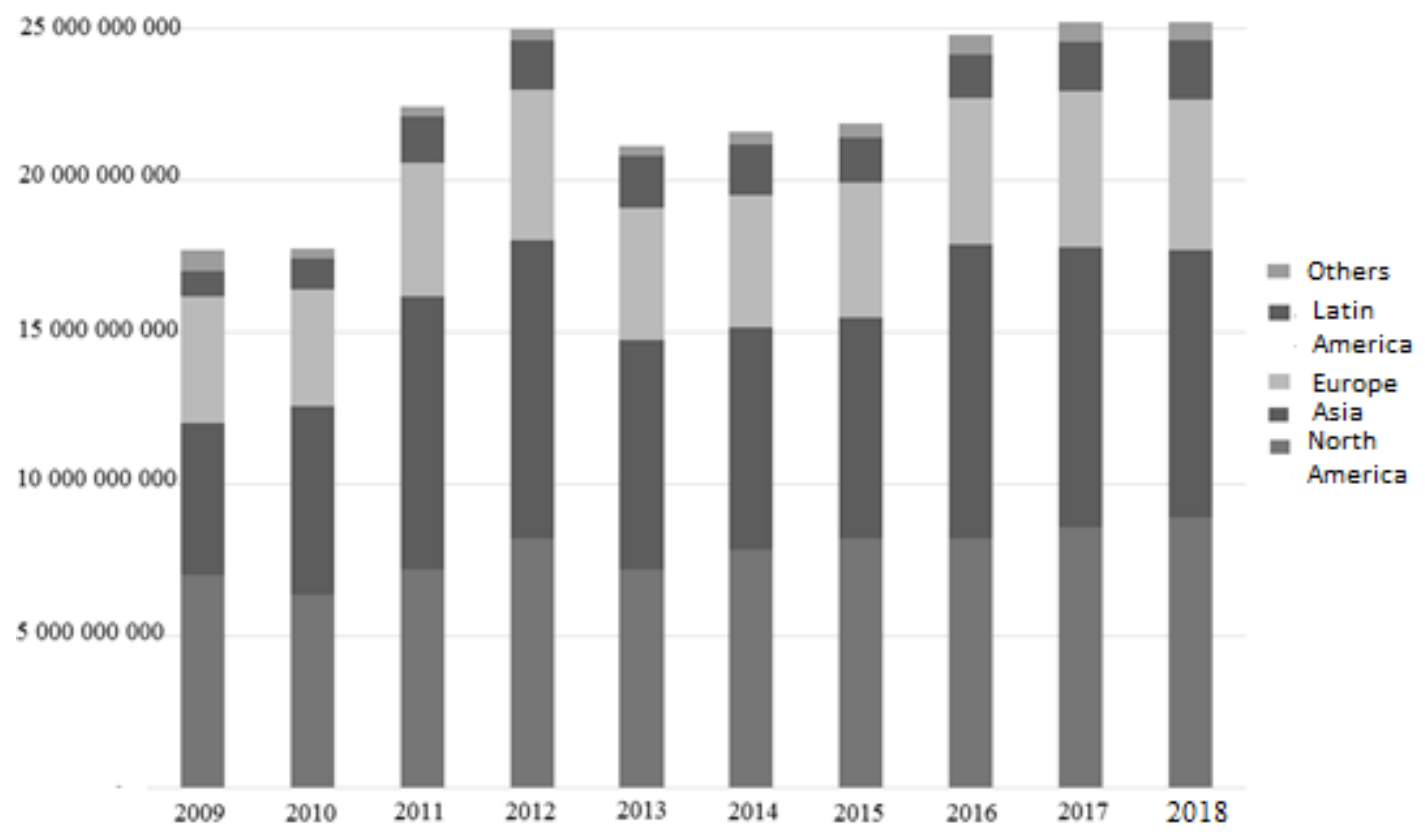

Figure 5. Dynamics of world electronic stock trading in 2008-2018 by regions of the world, billion contracts

Source: [1].

An analysis of electronic stock trading trends also indicates that more and more people today are inclined to trust the management of exchange operations for artificial intelligence, a high-complexity trading program that constantly scans specialized sources of information for keywords. These keywords indicate price fluctuations across the various marketplaces in the world. For milliseconds, the system evaluates the state of affairs in the market and automatically sells its authorized share of the stock or spends a userspecified amount on the purchase of certain securities. One can complete all the same work in about half an hour, and an experienced professional - in 15 minutes. During this time, the situation on any stock market can change dramatically. According to analysts, about 5 trillion \$ private investors will be invested by 2025 based on automatic recommendations of different software systems [12].

Today, artificial intelligence is managing an amount in excess of 19 million $\$$. Revenues from their use exceed the financial losses caused by incorrect forecasting. Figure 6 shows the dynamics of the share of electronic stock exchange operations performed not by a person but by a trading robot.

In addition to robotic traders, the development of specialized applications is increasingly intensified, which further simplifies electronic stock trading. A world-known BlackRock company with about 5 trillion $\$$ assets created its own app of the same name. According to investors, it is created based on algorithms used by the brokers themselves.

Another financial corporation Charles Schwab has launched its own Charles Schwab Intelligent Portfolios service. Its main feature is the low "threshold of entry" - the user needs to invest $\$ 5$ thousand, without a fee. The program encourages clients to invest in exchange-traded index funds. But its effectiveness is not yet easy to evaluate since the project started recently. 


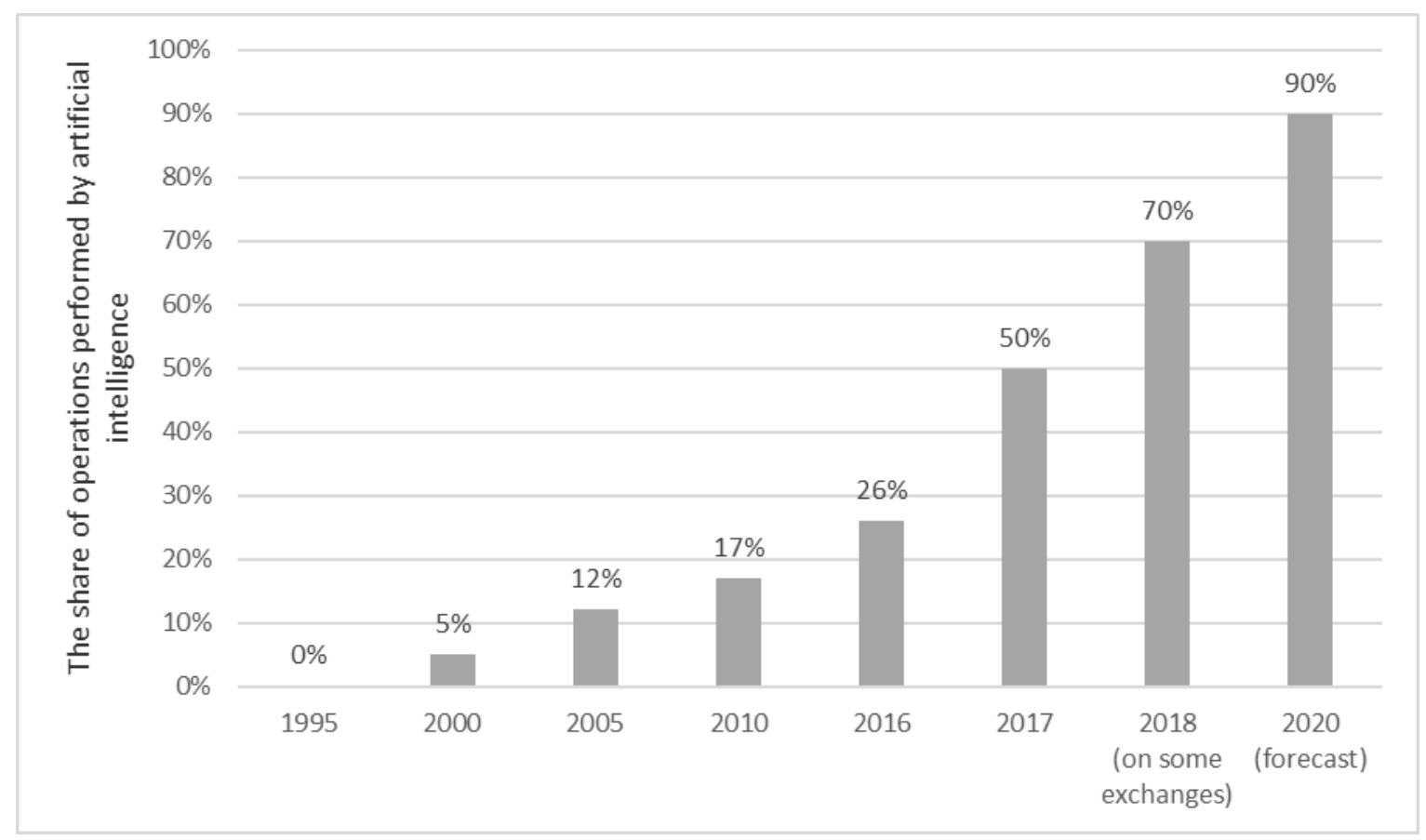

\section{artificial intelligence}

Figure 6. Dynamics of the share of electronic stock exchange transactions performed by the Source: [12].

Conclusions from the research. On the basis of such active dynamics of stock indices of electronic stock platforms, which was demonstrated on the example of Nasdaq Composite and Euronext NV indices and dynamics of world electronic stock trading by regions, there are three positive and two negative interdependencies:

+ the growth of stock indices indicates the active development of the world economy. During the crises, the index quotations decrease (the period of the dotcom collapse) and during the periods of economic growth, on the contrary, there is a positive dynamics;

+ the growth of electronic stock exchange indices indicates that there is a demand among investors, which means that investors are optimistic about investing their financial assets within electronic stock exchange;

+ the growing dynamics of electronic stock indices testify to their active development and spread in the world. Every year, the role of electronic stock exchanges is increasing, as more and more electronic platforms are being created, and more and more operations are being done online;

- electronic stock indices are extremely sensitive to any changes in the economic situation. So the breakdown of the dotcoms and the global financial crisis led to one of the biggest falls in trends;

- although the overall dynamics of electronic stock indices is steadily increasing, however, the dynamics are very volatile over short periods of time.

Thus, in view of the conducted research it is worth noting that modern stock electronic trade is currently in the stage of its active development. The activities and dynamics of electronic stock exchanges can be tracked using stock indices of stock exchanges. The most common of these are quite active. It is also worth noting that the organization of electronic stock trading is significantly different from the classic trade mechanism. In particular, electronic stock exchange activities have their own particular aspects of operation, which make them the most organized and developed form of trading today. 


\section{Джерела та література}

1. Acworth W. 2016 Annual Volume SurveyGlobal Futures and Options Volume Reaches Record Level / W. Acworth // Market Voice. - 2016. - Volume 5 (2). - P. 58-79.

2. Сутність електронної біржової торгівлі [Електронний ресурс] - Режим доступу до ресурсу: http://ukr.vipreshebnik.ru/birzhova-diyalnist/2613-sutnist-elektronnoji-birzhovoji-torgivli.

3. Кузнєцова О. В. Електронні біржі [Електронний ресурс] / О. В. Кузнєцова // Одеська Національна академія харчових технологій. - 2013. - Режим доступу до ресурсу: https://ukrbukva.net/74081-Elektronnyebirzhi.

4. Костюченко О. А. Банківське право: підручник для студентів економічних спеціальностей вищих навчальних закладів / О. А. Костюченко. - К. : Атіка, 2011. - 376 с.

5. Кушнір Т. Б. Економіка і організація біржової торгівлі : навч. посіб. / Т. Б. Кушнір. - Харків : Консум, 2003. - $216 \mathrm{c}$.

6. Офіційний ресурс ТОВ «Національна Електронна Біржа» [Електронний ресурс] - Режим доступу до pecypcy: https://neb.org.ua.

7. Енциклопедичний словник економіки та права [Електронний ресурс] - Режим доступу до ресурсу: https://dic.academic.ru/dic.nsf/dic_economic_law/18326/ЭЛЕКТРОННАЯ.

8. Електронні системи торгів [Електронний ресурс] // Бібліофонд. - 2013. - Режим доступу до ресурсу: http://www.km.ru/referats/333722-elektronnye-sistemy-torgov.

9. Електронні торгові системи [Електронний ресурс] // Магазин инвестиционных фондов - Режим доступу до ресурсу: http://www.vunt.ru/trader/6.

10. Дудяк Р. П. Організація біржової діяльності: основи теорії і практикум : навч. посіб. / Р. П. Дудяк, С. Я. Бугіль. - 2-е вид., допов. - Львів : Новий Світ-2000 ; Київ : Магнолія плюс, 2018. - 360 с.

11. Офіційний ресурс американської електронної фондової біржі [Електронний ресурс] - Режим доступу до ресурсу: https://www.nasdaq.com.

12. Офіційний ресурс пан-європейської фондової біржі Euronext NV [Електронний ресурс] - Режим доступу до ресурсу: https://www.euronext.com/en.

\section{References}

1. Acworth W. (2016). Annual Volume SurveyGlobal Futures and Options Volume Reaches Record Level. Market Voice Magazine [in English].

2. Vojevodina T. (2019). Sutnistj elektronnoji birzhovoji torghivli [The essence of electronic stock trading]. Electronic resource: http://ukr.vipreshebnik.ru/birzhova-diyalnist/2613-sutnist-elektronnoji-birzhovoji-torgivli [in Ukrainian].

3. Kuznetsova O. V. (2013). Elektronni birzhi [Electronic exchanges]. Electronic resource: https://ukrbukva.net/74081-Elektronnye-birzhi [in Ukrainian].

4. Kostjuchenko O. A. (2011). Bankivsjke pravo: pidruchnyk dlja studentiv ekonomichnykh specialjnostej vyshhykh navchaljnykh zakladiv [Banking Law: A Textbook for Students of Economic Specialties of Higher Education]. Kyiv: Atika [in Ukrainian].

5. Kushnir T. B. (2003). Ekonomika i orghanizacija birzhovoji torghivli [Economics and organization of stock trading]. Kharkiv: Consum [in Ukrainian].

6. Official Resource of National Electronic Exchange LLC. Electronic resource: https://neb.org.ua [in Ukrainian].

7. Encyklopedychnyj slovnyk ekonomiky ta prava [Encyclopedic Dictionary of Economics and Law]. Electronic resource: https://dic.academic.ru/dic.nsf/dic economic law/18326/ЭЛЕКТРОННАЯ [in Ukrainian].

8. The Library Fund (2018). Elektronni systemy torghiv [Electronic trading systems]. Electronic resource: http://www.km.ru/referats/333722-elektronnye-sistemy-torgov [in Ukrainian].

9. Investment Fund Resource. Elektronni torghovi systemy [Electronic trading systems]. Electronic resource: http://www.vunt.ru/trader/6 [in Russian].

10. Dudjak R. P. (2018). Orghanizacija birzhovoji dijaljnosti: osnovy teoriji i praktykum [Organization of stock exchange activities: basics of theory and practicum]. Lviv: New World-2000; Kyiv: Magnolia plus [in Ukrainian].

11. The official resource of the American electronic stock exchange. Electronic resource: https://www.nasdaq.com [in English].

12. The official resource of the pan-European stock exchange Euronext NV. Electronic resource: https://www.euronext.com/en [in English]. 